\title{
Research on the Situation of Old-age Care in Shaanxi Province
}

\author{
Xiaojing DONG \\ Xijing University, Xi'an, Shaanxi, China \\ e-mail: 664186437@qq.com
}

\begin{abstract}
Old-age care is a problem in China. Shaanxi faced the problem in 2002. Now the total population of the province broke through 37930 thousands. At the same time the number of old people whose age is over 65, is 38347 thousands. There lie in three kinds of modes in old-age care, which are Home-based Care, Nursing Homeland Community Retirement for the aged. The paper analyses the current situation of old-age care in Shaanxi province in China.
\end{abstract}

Keywords-old-age Care; the traditional family mode; the institution mode; the community endowment services

\section{INTRODUCTION}

Population aging is the dynamic process in a country or a region, where the proportion of elder population is increasing but the proportion of young people is decreasing. That means the number and the ratio of the old ages is higher. International view shows: a country or a region is made of old people (aged over 60), over 10 percents in all or old people (over 65) are over 7 percents.

Early the percent of old people (Aged > $=65$ ) in Shaanxi was over 7\% in 2002.It means Shaanxi is a society of population aging.

TABLE I. AGE COMPOSITION IN SHAANXI

\begin{tabular}{|c|c|c|c|c|c|c|}
\hline Year & 2010 & 2011 & 2012 & 2013 & 2014 & 2015 \\
\hline $\begin{array}{c}\text { Population Aged 60 and } \\
\text { Over (thousands) }\end{array}$ & 4796.6 & 4957.8 & 5201.0 & 5513.9 & 5842.8 & 6011.0 \\
\hline $\begin{array}{c}\text { Population By Aged 65 and } \\
\text { Over(thousands) }\end{array}$ & 3184.1 & 3259.8 & 3366.5 & 3549.2 & 3763.8 & 3834.6 \\
\hline
\end{tabular}

\section{RESEARCH ON THE SITUATION OF OLD-AGE CARE IN SHAANXI PROVINCE}

\section{A Family structure}

A couple has only a kid. The policy had been kept for over thirty years, so that it has happened that there are huge changes in family pension mode. At present, the whole family structure is ' $4-2-1$ ' inverted pyramid shape. Although the family planning policy was adjusted, which is 'the second child is permitted', it could alleviate the pressure of the endowment effect at least 18 years to emerge. Family members tend to be serious, professional modern society competition is intense and speeds up the pace of life in individuals, families facing huge pension pressure.

The current situation of old-aged care in Shaanxi is that three generations living, get fewer and fewer in living in a home. This means that traditional endowment way depend on their offspring continue old-age support and care service demanders spouse can provide old-age service is quite limited, therefore, based on community social endowment service supply is the inevitable choice to solve the problem of pension services.

\section{B Dependency ratio of population}

The term refers to the ratio of the population A (aged under 15 or over 64 ) to the general population $B$ (aged from 15 to 64 ). Its formula is namely A/B. Usually it is expressed as a percentage. It instructs that per 100 working-age people roughly afford the people whose ages are outside of working-age. It can tell us the burden of bearing. The value is larger and larger by year, which means that the burden of labor is more severe. Every family faces the huge burden of raising old people.

TABLE II. AGE COMPOSITION AND DEPENDENCY RATION OF POPUlation

\begin{tabular}{|c|c|c|c|c|c|c|}
\hline Year & 2010 & 2011 & 2012 & 2013 & 2014 & 2015 \\
\hline $\begin{array}{c}\text { Percentage to Total } \\
\text { Population By Age } \\
(>=65)\end{array}$ & 8.53 & 8.71 & 8.97 & 9.43 & 9.97 & 10.11 \\
\hline $\begin{array}{c}\text { Dependency ratio } \\
\text { of population (\%) }\end{array}$ & 11.11 & 11.35 & 11.71 & 12.36 & 13.13 & 13.34 \\
\hline
\end{tabular}

\section{ANALYSIS OF THREE MODES OF OLD-AGE CARE IN SHAANXI PROVINCE}

There lie in three social pension security modes of old-age care, such as the traditional family pension mode, the institution endowment mode and family Community care mode for the aged. 


\section{A The traditional family pension mode}

Traditional family pension model in China has been kept for thousands of years. It is based on kinship ties and family, young members provide a series of living arrangements, such as food, clothing and shelter for the old untilold people are dead. This is the domestic 'feedback type' model of pension, which is founded on rural society, namely a man has kept labor in his life time and for his family. The pension mode needs its profound economic, cultural and social foundation.

Today, Chinese social transformation is from tradition to modern times. In Chinese economy, politics, culture and society, great changes have taken place. At the same time, under the impact from the multi-culture and values of the modern society, more and more people leave from earth land rural family scale is smaller in diminution, in that empty nesters occur. These change modern family structure and people's ideas about a trend of weak on traditional family providing for the aged. The tradition family supply for the aged, the pattern has undergone grave impact and is facing a severe challenge.

\section{B The institution endowment mode}

The institution endowment is a term of social pension, which refers to the comprehensive service, providing food, living, cleaning, living nursing, health management and recreational activities for the elderly. It can be an independent legal entity, or a department or a branch affiliated to the medical establishment, enterprises, institutions, social organizations or comprehensive social welfare organizations.

Now the mode lies in some problems. At first, the public policy support for institutional pension is not balanced. The government institution has received a large amount of public financial support, but there is a lack of scientific management. Many private pension institutions cannot receive preferential treatment and financial support, making it difficult to develop. Then, the supply and demand of institutional pension are outstanding, and the supply and demand structure is unbalanced. The total supply is grossly inadequate. Beds are difficult to sum up, and the structural contradictions are prominent. At last, the old-age institutions have extensive management and lack of professional service standards.

It is the key of the endowment service reform. First, it clarifies the social endowment service to take each responsibility between institution and dweller's deputy. Second, it should establish a sound legal mechanism of social organizations to participate in, will gradually endowment service socialization and specialization. The types belong to institution endowment. If the family mode that continue thousands of years can be replaced by the society mode?

\section{The Community Endowment Services mode}

In this way, the community endowment mode is then created under the new situation. In the 1960s, developed countries put forward the theory 'endowment in the suitable environment'. Until the 1980s, community endowments was not developed and culminated in the western developed countries. They are good at enacting relevant laws and local policies. In the project, they succeed in building a strong link between the school and the community, and attract volunteers and high-quality staff. The provincial government has explored suitable for Shaanxi's provincial conditions and be able to solve the problem of aging society in Shaanxi's endowment pattern, is the priority of Chinese academia, government and society. USA Today reported, the explosive growth of the US elderly population is fueling a grass-roots 'village' movement in neighborhoods across the country to help people age in their own homes.

Community endowment Services is combined family pension and institution endowment. It is embodied that old man lives in his home, gets care services, with door-to-door service, nursing home service, delivering to the door, accompany shopping and washing clothes ,etc, which is integrated society endowment patterns of strength.

In contrast, community endowment combines the advantages of family supported endowment and institutions supported endowment, which will become a new choice for endowment. In this case, the service of Community Endowment Services, which combines with the advantages of above two modes, will become the main means for Shaanxi's urban elderly in the future. Community Endowment Services can satisfy the majority of people to provide adequate health care network, care, canteen set up, to bring food home, as well as door-to-door, accompanied shopping, laundry help. In choosing modern social modes of providing for the aged, it is feasible to actively establish and improve the social mode on the basis of fully affirming and exerting the family function.

\section{The relevant conclusion and proposal}

Now, there are a series of problems in the community old security. Due to the current old-age community services are imperfect, there are still enough to take care of daily life such as the elderly, inadequate health care network. With insufficient funding, some community nursing facilities sit idle or are diverted to other purposes.

To build a harmonious society in Shaanxi, for older people to live healthy, happy, quality, meaningful, we must strengthen the human resources services to the community. The key to solve the aging problem in provincial cities lies in the settlement of senior citizen sup- porting. While economy is developing constantly, the village has implemented the old community security for the member of community in order to ensure the old can get what they want.

\section{ACKNOWLEDGEMENT}

This research was financially supported by the Shaanxi Science and Technology Department support (2016KRM117).

\section{REFERENCES}

[1] China statistical yearbook 2016, China Statistics Press

[2] Shaanxi Province statistical yearbook 2016, China Statistics Press

[3] How to Resolve the Problem of Old People in CHN, Xiao-jing Dong 2017, Destech Publications Inc 